\section{Study on The Effect of Cold-Rolling and Subsequence Welding on the Corrosion Rate of 304L}

\author{
Niko Arianto, Suwarnd \\ Department of Mechanical Engineering, Institut Teknologi Sepuluh Nopember, Surabaya 60111, Indonesia \\ Received: 6 January 2019, Revised: 3 March 2019, Accepted: 16 March 2019
}

\begin{abstract}
Corrosion is an event of material damage due to reacting chemically with the environment. Stainless steel is a widely used steel in the industrial world, for example, the austenitic stainless-steel type 304L. The problem that still arises with 304L stainless steel is corrosion at grain boundaries. The sensitization process occurs when the steel is heated at a temperature of $500^{\circ} \mathrm{C}-700^{\circ} \mathrm{C}$ resulting in chromium carbide precipitation formation. Sensitization of austenitic stainless steel can occur during the welding process, which can cause damage to the heat-affected zone (HAZ). Cold working on metals is a deformation process that is carried out at temperatures below the recrystallization temperature. This research was conducted to determine the effect of variations in rolling and welding. Rolling was carried out using a cold working process with a variation of the workpiece reduction, namely $20 \%$, $40 \%$, and $60 \%$. Welding was carried out with current variations of 50, 65, and 80 with a welding time of $5 \mathrm{~s}$ and $10 \mathrm{~s}$. The corrosion rate was tested using a potentiostat to obtain current density $\left(I_{\text {corr }}\right)$ and potential $\left(E_{c o r r}\right)$ data. From the research, it was found the relation between rolling, welding parameters, and the corrosion rate. The corrosion rate is controlled by the carbide precipitation in the HAZ regime.
\end{abstract}

Keywords: AISI 304L steel, cold working, corrosion rate, GTAW welding

\section{Introduction}

Corrosion is a common degradation mechanism in metallic materials because of chemical reactions with the environment. Corrosion properties are an important consideration in choosing materials for many industrial applications. Stainless steel with $18 \% \mathrm{Cr}$ and $8 \% \mathrm{Ni}$ has an austenitic phase and widely used. Austenitic 304L is stainless steel with low carbon and is a widely used steel because of its corrosion properties.

In many cases, a problem that arises in 304L stainless steel is intergranular corrosion and well established caused by carbide precipitation [1,2]. During slow cooling from a temperature of $480^{\circ} \mathrm{C}-680^{\circ} \mathrm{C}$, there is a sensitization that will result in chromium carbide precipitation formation [3]. One of the sensitizations of austenitic stainless steel can occur during the welding process, which can cause damage to the weld. Damage to the welds is caused by intergranular corrosion in the heat-affected zone (HAZ). This happens when the Cr content is below $12 \%$, the steel and is not resistant to corrosion because there is a chromium depletion at the grain boundaries. HAZ is the most critical area of the welded joint because changes in structure and changes in properties occur in this area, and it depends on the welding parameters [4,5].

Cold working on metals is a deformation process that is carried out at temperatures below the recrystallization temperature. The cold working process increases the strength of the material it contains residual stress and changes the corrosion properties [6-10]. The cold rolling process and annealing treatment afterward change the grain's structures. These grain boundary changes have been known can be controlled to reduce the corrosion rate of austenitic stainless steel [11-13].

The present work shows the effect of cold rolling and the subsequent welding on the corrosion rates of AISI 304L. The studied austenitic stainless steel is colled rolled in various degrees and then autogenously welded with gas tungsten arc welding (GTAW) process.

\section{Material and Methods}

The material to be used in the present study was stainless steel 304L and was tested for chemical composition before other treatments. Table 1 shows the chemical composition obtained from the optical spectrometry test. It can be seen that the steel is composed of $0.04 \% \mathrm{C}$, which is common for the 304L. The sample was a plate with $4 \mathrm{~mm}$ thickness with the width of $50 \mathrm{~mm}$ and $250 \mathrm{~mm}$ length and was rolled into the heavy rolling equipment. The cold working process reduces the thickness of the workpiece by about $0.1 \mathrm{~mm}$ to $0.5 \mathrm{~mm}$, and it was $20 \%$, $40 \%$, and $60 \%$ cold-rolled degree reduction.

"Corresponding author. Email: warno@me.its.ac.id 
Table 1. Chemical composition of steel from optical emission testing.

\begin{tabular}{|c|c|c|c|c|c|c|c|}
\hline \multirow{2}{*}{ Steel } & \multicolumn{7}{|c|}{ Chemical Composition (\%) } \\
\cline { 2 - 8 } & $\mathbf{C}$ & $\mathbf{S i}$ & $\mathbf{M n}$ & $\mathbf{N i}$ & $\mathbf{S}$ & $\mathbf{C r}$ & $\mathbf{F e}$ \\
\hline \multirow{2}{*}{ 304L } & 0.0430 & 0.435 & 1.68 & 8.53 & 0.0048 & 18.6 & Balance \\
\cline { 2 - 8 } & 0.0395 & 0.429 & 1.91 & 8.81 & 0.0055 & 18.8 & Balance \\
\hline Average & 0.0413 & 0.432 & 1.795 & 8.67 & 0.0052 & 18.7 & Balance \\
\hline
\end{tabular}

The autogenous welding process was done on the cold-rolled steel, and no heat treatment was performed before or after the welding process. The welding process was done on a specific spot without any movement with variations of current from 50,65, and $80 \mathrm{~A}$ for $5 \mathrm{~s}$ and $10 \mathrm{~s}$ for each sample. The shielding gas used during welding was Argon, in straight polarity currents (DCSP) mode.

The linear sweep voltammetry using a potentiostat is a common method to evaluate the corrosion rate of metals [14, 15]. In the present work, corrosion rate testing was carried out in a Metrohm Autolab in three-electrode cells set up. Data acquisition was with NOVA 1.8 software. Three-electrode cells were sample as the working electrode, a platinum counter electrode, and a reference Electrode. Tests using potentiostats were carried out to obtain current density $\left(I_{c o r r}\right)$ and potential $\left(E_{c o r r}\right)$. A $10 \mathrm{~mm} \times 10 \mathrm{~mm}$ specimen to be tested was connected by copper wire and mounted using a resin, so that during the testing only the surface of the material reacted. The surface of the test specimens was ground and polished with a roughness rating of $600,800,1000$, and 1500 prior to the test. The example of specimen and test cell is shown in Figure 1. This applied to all specimens to be tested because the treatment must be the same. The sample was tested with a linear Polarization mode with a step of $0.01 \mathrm{~V} / \mathrm{s}$

\section{Result and Discussions}

\subsection{Macro Observation}

Figure 2 shows an example of macro images of the welded, polished and etched samples. The images show the welded sample with a corona-like rather bright area, which is the heat-affected zone (HAZ). It can be seen from the figure that the diameter of the HAZ is the function of the current and time which is actually the heat input. The heat-affected zone is the area where the precipitation of carbide occurs preferentially at a specific temperature, $500^{\circ} \mathrm{C}-800^{\circ} \mathrm{C}$; thus, it only appears at a specific location depending on the thermal cycle of the welding.

\subsection{Corrosion Rate Testing}

The corrosion rate was tested in a three-electrode potentiostat. The parameters used were the specimen density of $7.9 \mathrm{~g} / \mathrm{cm}^{3}$, the equivalent weight of the specimen $25.974 \mathrm{~g} / \mathrm{mol}$, and the area of the specimen $1 \mathrm{~cm}^{2}$. Figure 3 is an example of the curve of the test results of the corrosion rate of AISI 304L steel with a rolling reduction of $60 \%$ and welding current of $65 \mathrm{~A}$ for $10 \mathrm{~s}$.

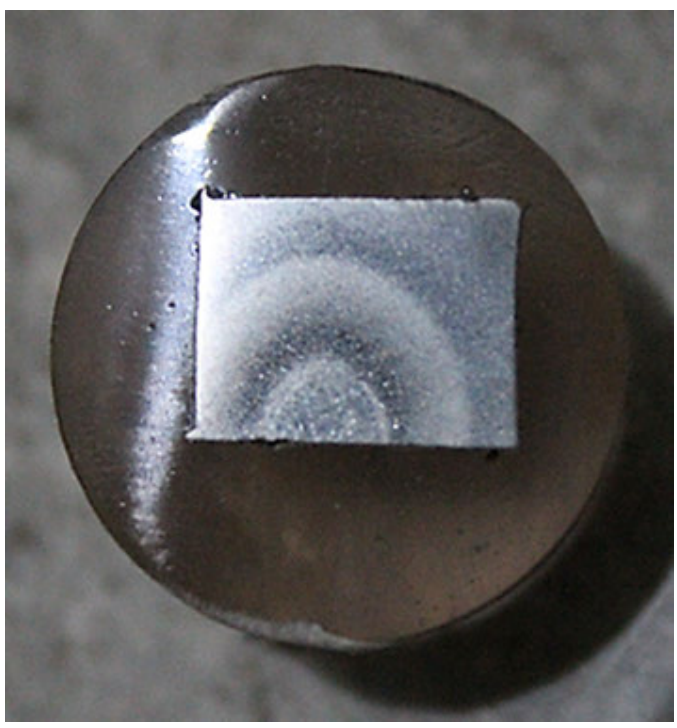

(a)

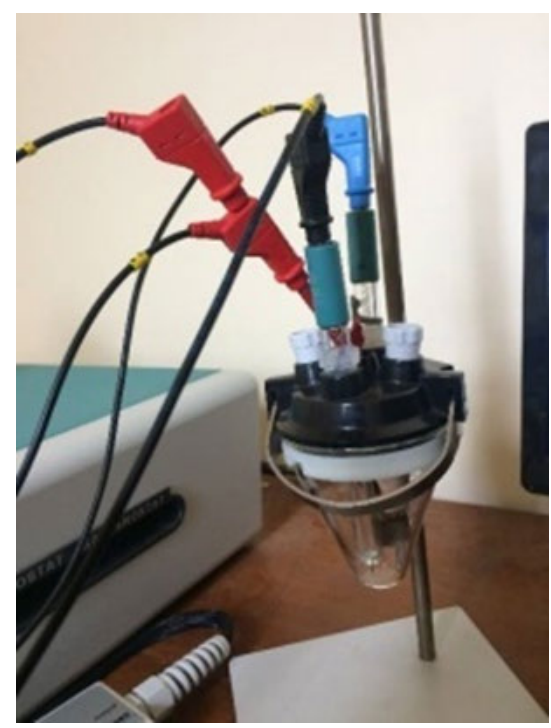

(b)

Figure 1. (a) An example of corrosion specimen where the tested sample is embedded in the epoxy resin. (b) The installation during the corrosion testing; WE (red), RE (blue), and CE (black). 


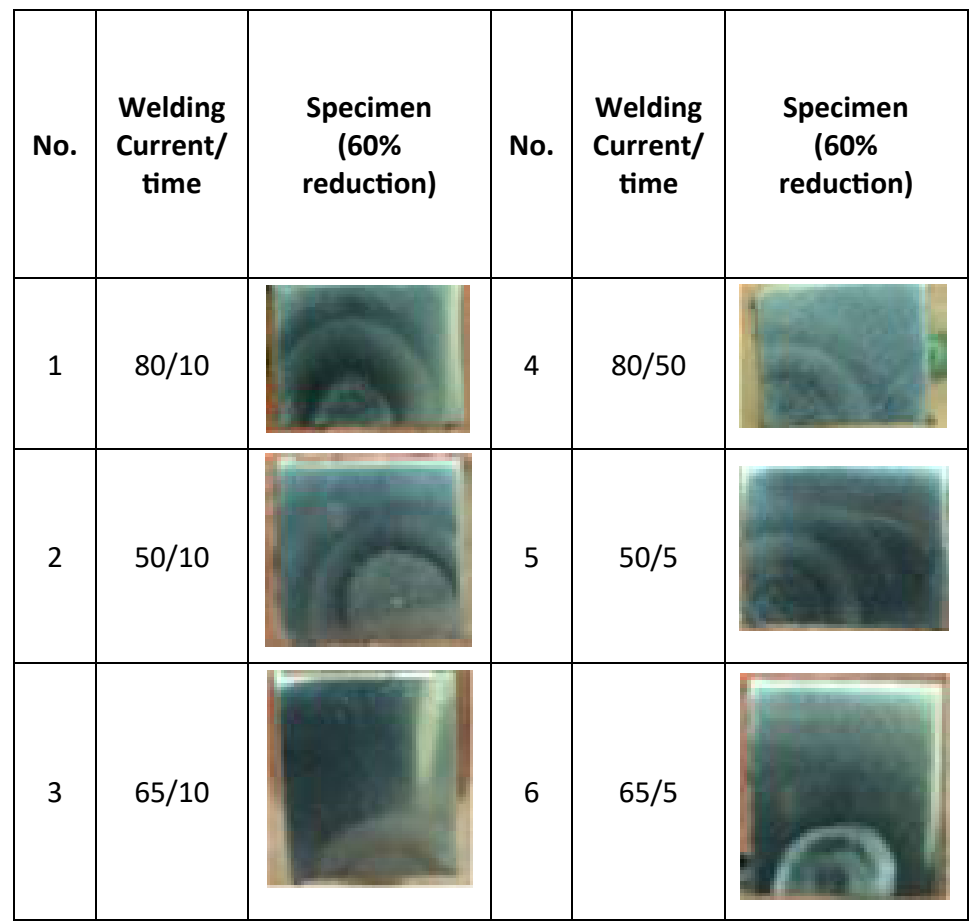

Figure 2. Macro photos of the specimen after welding in this case for $60 \%$ cold-rolled sample welding at various parameters.

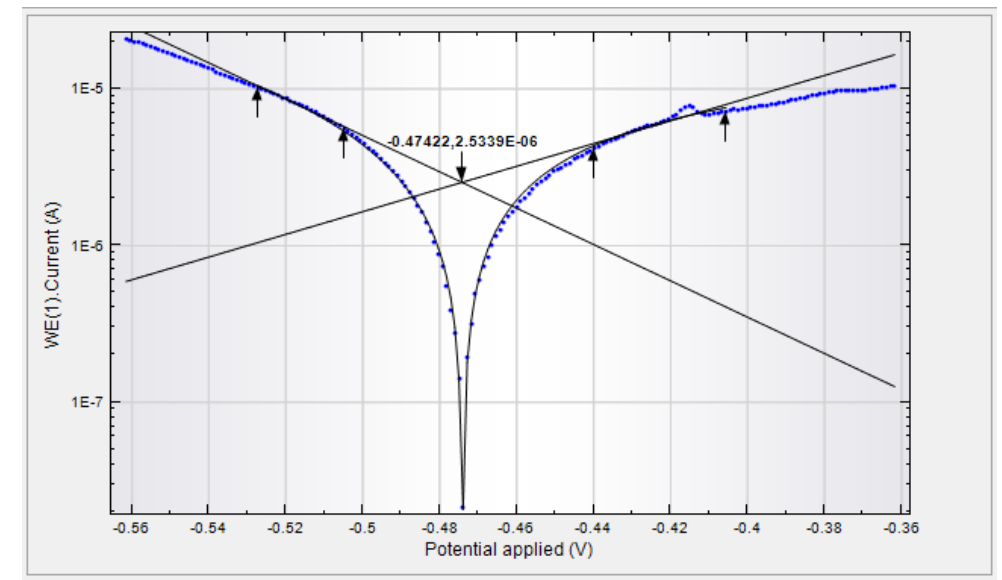

Figure 3. A typical polarization curve was obtained from the testing specimen with a welding current of 65 A, $60 \%$ cold-rolled reduction, and welding time of $10 \mathrm{~s}$.

The curve was formed because during the testing process. There is a redox reaction process at the electrode. Anodic curve occurred when the working electrode was energized by an electric current with a metal element that was previously neutral then released electrons to form ions. Conversely, in the cathodic curve, the reaction that occurred was the capture of the electrons released by the anode reaction. In the polarization curve, the corrosion rate value was determined at the $E_{c o r r}$ vs $\log I_{\text {corr }}$ intersection. The intersection line between $\log I_{\text {corr }}$ vs $E_{\text {corr }}$ was at $\left(-0.47422,2.5339 \times 10^{-6}\right)$.

After obtaining $I_{\text {corr }}$ Equation 1 , the calculated corrosion rate of $0.1122 \mathrm{~mm} /$ year. A similar methodology was used to calculate the other samples, and the result is shown in Table 2 .

$$
C R=\frac{0.00327 I E W}{D}
$$

Where:

$$
\begin{array}{ll}
C R & =\text { Corrosion rate }(\mathrm{mm} / \text { year }) \\
I & =\text { Current density }\left(\mu \mathrm{A} / \mathrm{cm}^{2}\right) \\
E W & =\text { Equivalent weight }(\mathrm{gram} / \mathrm{mol}) \\
D & =\text { Density of material }\left(\mathrm{gram} / \mathrm{cm}^{3}\right)
\end{array}
$$

Figure 4 and Figure 5 show corrosion rates at var- 
ious percentages of cold rolling at welding current at $5 \mathrm{~s}$ and $10 \mathrm{~s}$, respectively. In general, the welding current at $65 \mathrm{~A}$ has the lowest corrosion rate value compared to currents of $50 \mathrm{~A}$ and $80 \mathrm{~A}$ for every degree of reduction of rolling. It can be seen that the welding corrosion rate increased as the welding current of $80 \mathrm{~A}$. This relates to the effect of the high heat input had given so that a wider HAZ was formed, and a weld decay occurs at this area. The highest corrosion rate was obtained for the $60 \%$ reduction with the welding current of $80 \mathrm{~A}$, i.e. $0.225 \mathrm{~mm} /$ year. In contrast, the lowest corrosion rate was

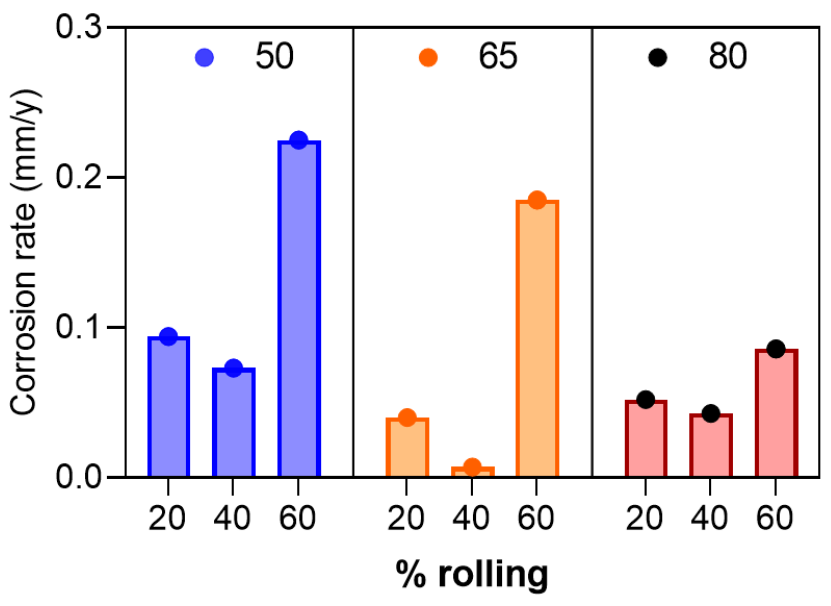

Figure 4. Corrosion rate at several rolling degrees at various welding current at $5 \mathrm{~s}$ welding time. obtained from the $40 \%$ rolling material with a current of $65 \mathrm{~A}$ of $0.0072 \mathrm{~mm} /$ year. The effect of longer welding time is identical, as shown in Figure 5 for 10 s welding time. As in $5 \mathrm{~s}$ of welding time, it can be seen that the welding results with a current of $80 \mathrm{~A}$ had an increase in the corrosion rate. The highest corrosion rate was obtained from the reduction material of $60 \%$ with a welding current of $80 \mathrm{~A}$ of $0.253 \mathrm{~mm} /$ year. In contrast, the lowest corrosion rate was obtained from a $40 \%$ reduction specimen with a current of $65 \mathrm{~A}$ of $0.0024 \mathrm{~mm} /$ year.

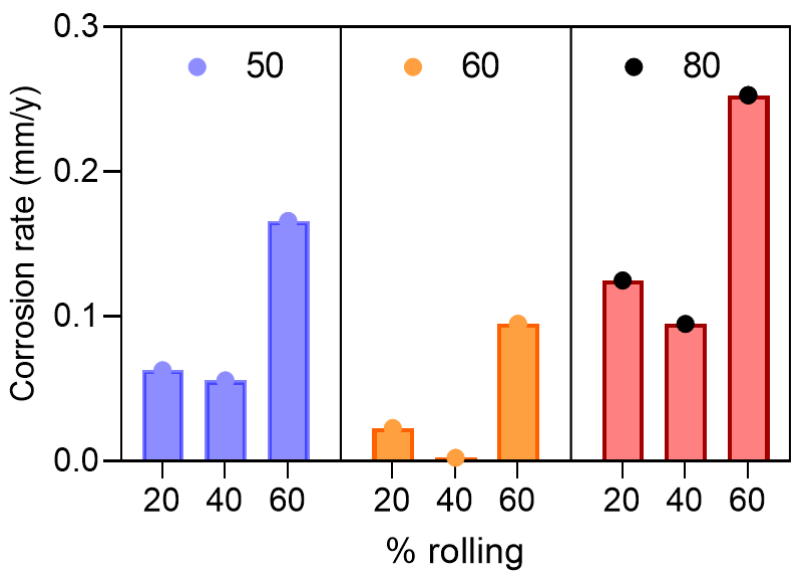

Figure 5. Corrosion rate at several rolling degrees at various welding current at $10 \mathrm{~s}$ welding time.

Table 2. The corrosion current and corrosion rate data for all sample tested.

\begin{tabular}{|c|c|c|c|c|c|}
\hline Sample & $\begin{array}{c}\% \\
\text { rolling }\end{array}$ & Time (s) & $I(\mathrm{~A})$ & $\begin{array}{c}\boldsymbol{I}_{\text {corr }} \\
\left(\mu \mathrm{A} / \mathbf{c m}^{2}\right)\end{array}$ & $\begin{array}{c}\text { Corrosion } \\
\text { rate } \\
\text { (mm/year) }\end{array}$ \\
\hline 1 & \multirow{6}{*}{ No-rolling } & \multirow{3}{*}{5} & 50 & 2.4450 & 0.0260 \\
\hline 2 & & & 65 & 0.2387 & 0.0038 \\
\hline 3 & & & 80 & 16.5500 & 0.1780 \\
\hline 4 & & \multirow{3}{*}{10} & 50 & 4.3650 & 0.0044 \\
\hline 5 & & & 65 & 1.1806 & 0.0130 \\
\hline 6 & & & 80 & 0.4034 & 0.0470 \\
\hline 1 & \multirow{6}{*}{20} & \multirow{3}{*}{5} & 50 & 8.7688 & 0.0940 \\
\hline 2 & & & 65 & 6.6790 & 0.0730 \\
\hline 3 & & & 80 & 20.8963 & 0.2250 \\
\hline 4 & & \multirow{3}{*}{10} & 50 & 15.3976 & 0.0630 \\
\hline 5 & & & 65 & 5.2137 & 0.0560 \\
\hline 6 & & & 80 & 4.7110 & 0.1660 \\
\hline 1 & \multirow{6}{*}{40} & \multirow{3}{*}{5} & 50 & 3.7159 & 0.0400 \\
\hline 2 & & & 65 & 0.6236 & 0.0072 \\
\hline 3 & & & 80 & 17.1716 & 0.1850 \\
\hline 4 & & \multirow{3}{*}{10} & 50 & 8.7984 & 0.0230 \\
\hline 5 & & & 65 & 0.1472 & 0.0024 \\
\hline 6 & & & 80 & 0.1567 & 0.0950 \\
\hline 1 & \multirow{6}{*}{60} & \multirow{3}{*}{5} & 50 & 4.8766 & 0.0520 \\
\hline 2 & & & 65 & 0.7419 & 0.0860 \\
\hline 3 & & & 80 & 17.0504 & 0.0432 \\
\hline 4 & & \multirow{3}{*}{10} & 50 & 4.2091 & 0.1250 \\
\hline 5 & & & 65 & 8.8766 & 0.0950 \\
\hline 6 & & & 80 & 23.5704 & 0.2530 \\
\hline
\end{tabular}


Figure 6 shows plot corrosion rate as function welding current at various percentages of cold rolling at $5 \mathrm{~s}$ welding time. Specimen with a $20 \%$ reduction in rolling for a welding current of 80 A shows $0.225 \mathrm{~mm} /$ year. Meanwhile, the lowest corrosion rate was obtained from the material without rolling with a current of $65 \mathrm{~A}$ of $0.0038 \mathrm{~mm}$ /year. Figure 7 show that the material without the rolling process had a corrosion rate that continued to decrease with the increasing welding current. The highest corrosion rate was obtained from the reduction material of $60 \%$ with a welding current of $80 \mathrm{~A}$ of $0.253 \mathrm{~mm} /$ year. In contrast, the lowest corrosion rate was obtained from a $40 \%$ reduction specimen with a current of 65 A of $0.0024 \mathrm{~mm} /$ year. The sample with the lowest corrosion rate meant that it had the highest corrosion resistance.

\subsection{Microstructure}

The figure 8 shows the microstructure of base materials before rolling. It can be seen that microstructure is a typical microstructure with austenite phase stainless steel. After the rolling and subsequent annealing, the microstructure will change and contains a twin-boundary which is a part of the crystal that changes orientation to form a symmetrical twin to the original lattice [11, 16]. The twinning crystal part is an inverted image of the parent crystal due to the shear stress that acts. It is now known that boundaries with twins have low corrosion rate and thus can be used as grain boundaries engineering.

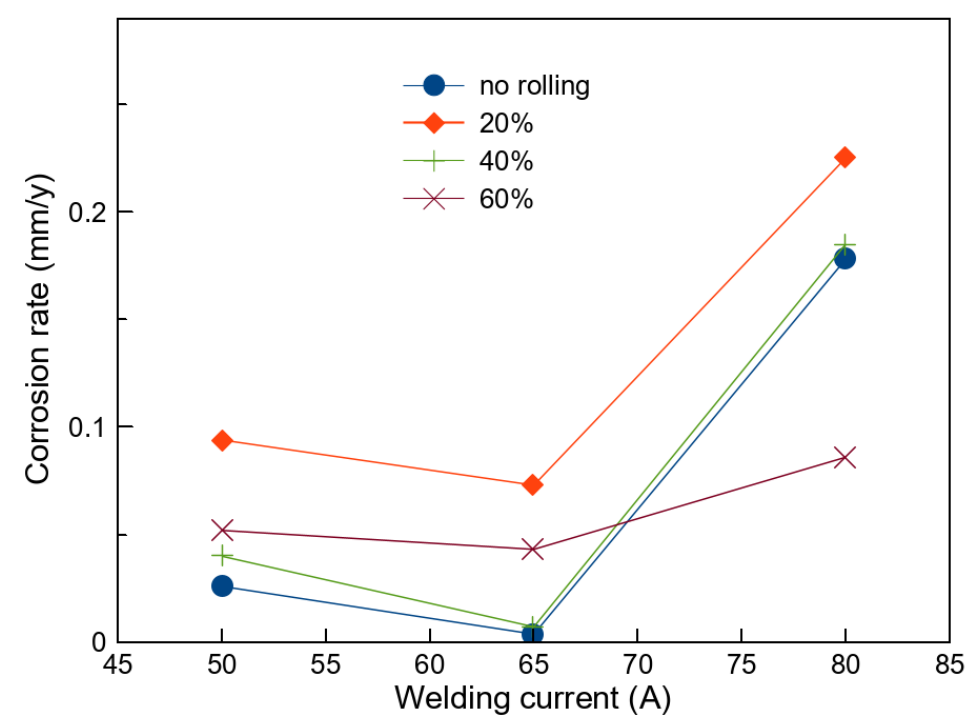

Figure 6. Corrosion rate as function of welding current at $5 \mathrm{~s}$ welding time for each reduction.

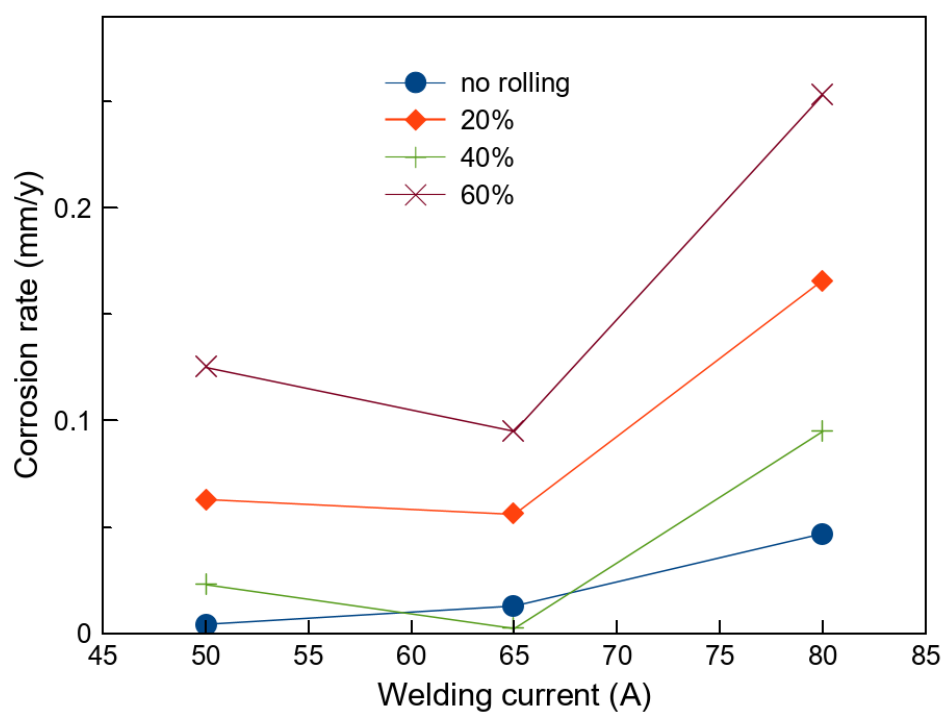

Figure 7. Corrosion rate as a function of welding current at $10 \mathrm{~s}$ welding time for each reduction. 
Figure 9 shows the microstructure of welded sample and HAZ region for the sample without rolling. It can be seen that there no significant chromium carbides precipitation at the grain boundaries. It is in agreement with the corrosion test that there is no significant corrosion rate for these samples at any level of welding current. Figure 10 shows the welded area and the HAZ of the sample with $20 \%$ cold rolling, and it can be seen that there is significant carbide precipitation can be observed in the HAZ.

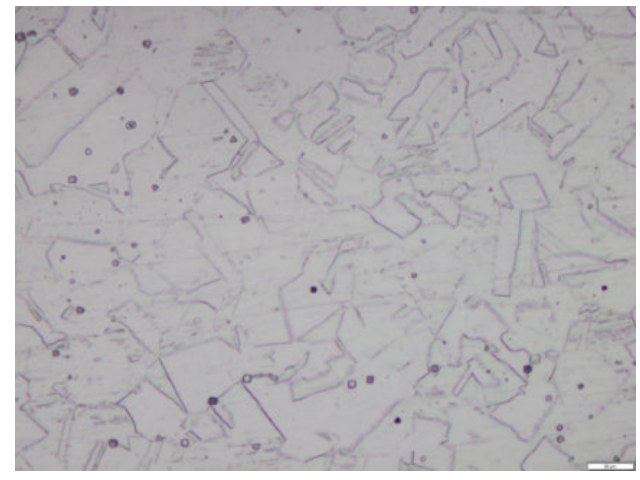

Figure 8. Stainless steel microstructure of the original metal without rolling and welding.

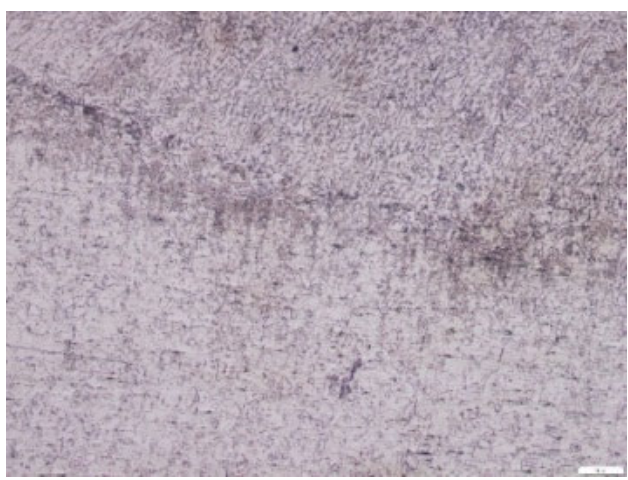

(a)

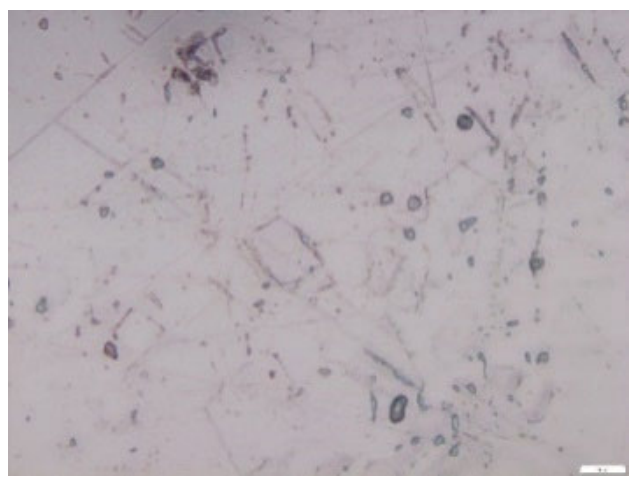

(b)

Figure 9. Microstructure for base metal with no rolling after welding at $80 \mathrm{~A}$ at $10 \mathrm{~s} \mathrm{(a)} \mathrm{The} \mathrm{fusion} \mathrm{line} \mathrm{area} \mathrm{with} \mathrm{the} \mathrm{parent}$ metal; (b) HAZ.

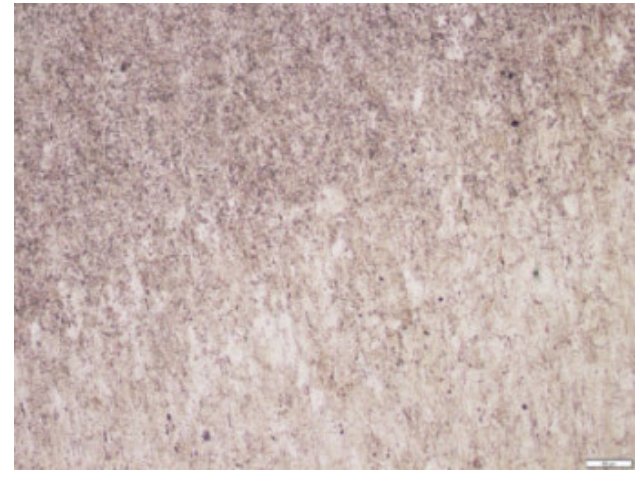

(a)

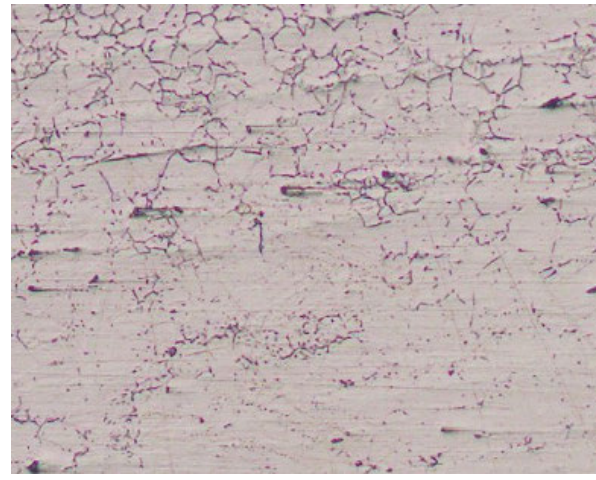

(b)

Figure 10. Microstructure for $60 \%$ cold-rolled sample after welding at $80 \mathrm{~A}$ at $10 \mathrm{~s}$ (a) The fusion line area with the parent metal; (b) HAZ. 
Statistical testing was used to determine the effect of cold rolling, welding time, and welding current as well as their three interactions to the corrosion rate of the welded AISI 304L. Based on factorial ANOVA using statistical software, the following results are obtained: 65 A current provided the lowest corrosion rate, while 80 A current produced the highest corrosion rate.

\section{Conclusions}

A study on the effect of cold-rolling and subsequence welding of AISI 304L on the corrosion rate has been done. The corrosion rate was evaluated with linear polarization using a potentiostat. A general trend was observed that rolling at $40 \%$ gives the lowest colling rate while there is no significant consistency for rolling at $20 \%$ and $80 \%$. Welding in 80 A give highest corrosion rate, and surprisingly there is no relation for the welding current and the corrosion rate for all the tested rolling degree. Nevertheless, welding at $65 \mathrm{~A}$ gives the lowest corrosion rate at all degrees of rolling. The microstructure studied shows that there is a clear relationship between the corrosion rate and the amount of carbide precipitation at the grain boundaries.

\section{References}

[1] A. Kinzel, "Chromium carbide in stainless steel," JOM, vol. 4, pp. 469-488, May 1952.

[2] E. Butler and M. Burke, "Chromium depletion and martensite formation at grain boundaries in sensitised austenitic stainless steel," Acta Metallurgica, vol. 34, pp. 557-570, Mar. 1986.

[3] S. Kou, Welding Metallurgy. John Wiley \& Sons, 2020.

[4] S. A. S. Suwarno, "Prediksi derajad presipitasi karbida krom pada baja tahan karat austenitik dengan metode jaringan syaraf tiruan," JTM, vol. 5, no. 2, 2004.

[5] F. Lacoviello, V. D. Cocco, and L. D’Agostino, "Analysis of the intergranular corrosion susceptibility in stainless steel by means of potentiostatic reactivation tests," Procedia Structural Integrity, vol. 3, pp. 269275, Jan. 2017.

[6] S. Ainur Ridho, "Pengaruh pengerolan dingin dan temperatur annealing terhadap ketahanan korosi integranular pada austenitic stainless steel tipe 304," Tugas Akhir, 2007.
[7] P. M. Ahmedabadi, V. Kain, B. K. Dangi, and I. Samajdar, "Role of grain boundary nature and residual strain in controlling sensitisation of type 304 stainless steel," Corrosion Science, vol. 66, pp. 242-255, Jan. 2013.

[8] L. Yahia, E. Nouicer, and F. Z. Benlahreche, "Effect of rolling deformation on corrosion behaviour of aisi 3041 in 3\% nacl solution," in Defect and Diffusion Forum, vol. 406, pp. 375-384, Trans Tech Publ, 2021.

[9] W. Feng, S. Yang, and Y. Yan, "Effects of deformation mode and strain level on grain boundary character distribution of 304 austenitic stainless steel," Metallurgical and Materials Transactions A, vol. 49, pp. 2257-2268, June 2018.

[10] M. Milad, N. Zreiba, F. Elhalouani, and C. Baradai, "The effect of cold work on structure and properties of aisi 304 stainless steel," Journal of Materials Processing Technology, vol. 203, pp. 80-85, July 2008.

[11] H. Kokawa, "Potential of grain boundary engineering to suppress welding degradations of austenitic stainless steels," Science and Technology of Welding and Joining, vol. 16, pp. 357-362, May 2011.

[12] H. Kokawa, M. Shimada, and Y. S. Sato, "Grainboundary structure and precipitation in sensitized austenitic stainless steel," JOM, vol. 52, pp. 34-37, July 2000.

[13] S. Tokita, H. Kokawa, S. Kodama, Y. S. Sato, Y. Sano, Z. Li, K. Feng, and Y. Wu, "Suppression of intergranular corrosion by surface grain boundary engineering of 304 austenitic stainless steel using laser peening plus annealing," Materials Today Communications, vol. 25, p. 101572, Dec. 2020.

[14] P. Morris and R. Scarberry, "Predicting corrosion rates with the potentiostat," Corrosion, vol. 28, pp. 444-452, Jan. 2013.

[15] S. Munir, M. H. Pelletier, and W. R. Walsh, "Potentiodynamic corrosion testing," Journal of visualized experiments: JoVE, Sept. 2016.

[16] M. Shimada, H. Kokawa, Z. Wang, Y. Sato, and I. Karibe, "Optimization of grain boundary character distribution for intergranular corrosion resistant 304 stainless steel by twin-induced grain boundary engineering," Acta Materialia, vol. 50, no. 9, pp. 23312341, 2002. 